\title{
Digital synapsis: dati, informazioni e modelli in connessione
}

\author{
Carlo Bianchini \\ Marika Griffo
}

Abstract

La rivoluzione tecnologica ha consentito una rapidissima crescita numerica ed un notevole sviluppo, in ambiente digitale, di modelli interpretativi tra loro molto differenti. Questo processo ha favorito, per certi versi, la diffusione, sia in termini di divulgazione che di disseminazione, dei dati e delle informazioni. Al contempo, tale rivoluzione ha generato una loro sovrabbondanza tanto da rendere spesso complicata la distinzione tra il dato ricercato e tutto ciò che non lo è (il cosiddetto 'rumore di fondo'). La ricerca qui proposta intende indagare i processi di integrazione di dati tipologicamente eterogenei in ambiente digitale e il modo in cui la loro struttura informatica influenzi la loro fruizione. L'ambito di applicazione è pertinente al patrimonio culturale costruito. L'obiettivo della ricerca è quello di predisporre una metodologia di indagine capace di innescare una continuità di processo tra i prodotti della conoscenza derivati

Parole chiave

modello concettuale, rilievo, Building Information Modeling, Level of Reliability, data integration.

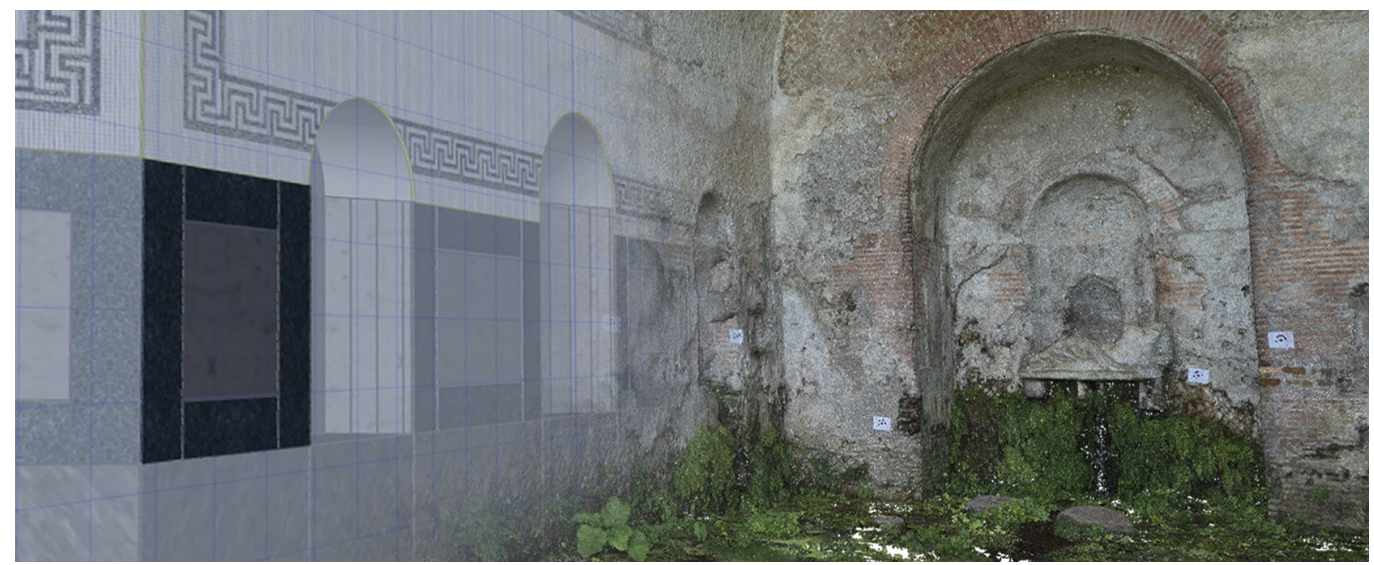




\section{Intersezioni digitali: la conoscenza come sistema complesso}

L'entropia nello spazio tridimensionale virtuale sembra inarrestabile. La creazione dei 'cloni digitali' pare essere l'unica precauzione efficace per assicurare che rimanga traccia del mondo reale, così come noi lo conosciamo, anche in futuro. Di fronte questa prospettiva pare evidente la necessità di comporre sistemi di gestione dei dati che diano l'ordine della produzione esistente e che ne assicurino l'intellegibilità futura.

La rappresentazione del patrimonio culturale costruito si trova ad indagare le possibilità di interazione tra dati eterogenei nel dominio del modello digitale. Questo approccio si affida ad un principio di complementarità dei processi di conoscenza finalizzato alla convergenza, in ambiente virtuale, dei diversi ambiti di indagine coinvolti.

Ogni spazio virtuale di ogni ambito di indagine viene abitato da dati, questi si compongono tra loro in forme sempre più complesse diventando informazioni e poi modelli.

Questi modelli vengono costruiti selezionando e processando solo alcune delle qualità dell'oggetto. Dal modello statistico predittivo a quello diagnostico, strutturale e geometrico, ogni processo di conoscenza ha una propria autonomia metodologica e procedurale. L'integrazione tra queste varie componenti può arvenire individuando uno spazio virtuale che si presti ad accogliere dati, informazioni e modelli tra loro diversi e che consenta di esplicitare il carattere proprio di ogni ambito di indagine.

In termini generali, la distinzione tra dati, informazioni e conoscenza è trattata dalla Information Science per definire dei gradi di complessità e sviluppo che intervengono nei processi cognitivi [Ackoff | 989]. Sebbene in ogni settore specifico tali livelli abbiano assunto nomi e, talvolta, significati abbastanza specifici, è possibile descrivere delle caratteristiche, per ogni livello individuato, comuni ai vari ambiti.

L'organizzazione dei processi conoscitivi è applicabile all'ambito della documentazione e della trasmissione del patrimonio costruito ed assume un significato particolare in riferimento al tema dell'integrazione di dati eterogenei. Nello specifico, al dato è possibile assimilare tutto ciò che descrive le proprietà dell'opera architettonica senza connotazioni specifiche, è l'input, ciò che viene inserito nel sistema per attivarlo. Le informazioni sono invece riferibili all'interpretazione rispetto al contesto, il dato viene elaborato e trasformato per assumere un significato. In riferimento al livello successivo di sviluppo, quello della conoscenza, è possibile leggere una specificità relativa al contesto specifico trattato. In esso, la conoscenza trova la sua configurazione attraverso il modello. La conoscenza dell'oggetto è il modello che lo studioso produce di esso.

Fig. I. Theo Kamecke, Az-Tech. Circuiti in oro 24 carati prodotti negli anni 60. II depotenziamento dell'informazione: il circuito elettronico è uno dei simboli più iconici dell'informazione digitale il suo uso decontestualizzato ne depotenzia izzato ne depotenzi conferirgliene un altro.

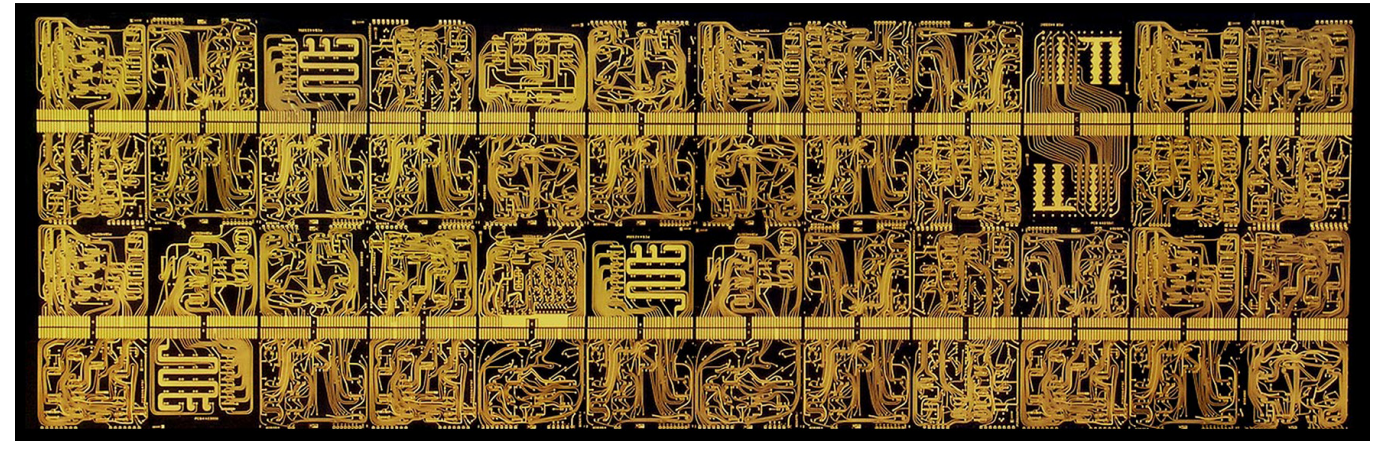

\section{L'integrazione: questioni aperte}

L'immagine del modello come rappresentazione tematica della realtà si è fin qui delineata insistendo su un piano concettuale e, per certi versi, autonomo rispetto ai modi ed agli strumenti adoperabili. II salto logico successivo porta a chiedersi se un certo livello di consapevolezza metodologica (modi) e tecnologica (strumenti) possa potenziare i ruoli del modello e conferirgliene di nuovi. 
Il perché delle integrazioni trova la sua radice nella necessità programmatica di raggiungere la conoscenza profonda dell'oggetto. Avendo la possibilità di accedere a disparati fattori descrittori, l'oggetto assume una configurazione propria in ragione della quale ogni dato inserito modifica l'insieme e contribuisce alla comprensione globale. Ciascuna modalità di indagine riferisce una diversità, ossia un valore aggiunto complementare agli altri capace di creare dei vincoli logici e concettuali necessari ad inquadrare il tutto. II concetto di analisi integrata è per gli esseri umani innato, siamo abituati a fare esperienza del reale combinando con disinvoltura i nostri sensori, ovvero i nostri sensi, e conoscendo il mondo esterno attraverso essi; è in questa chiave che lo sviluppo sempre crescente di studi relativi alla data fusion assume un ruolo di prim'ordine indipendentemente dall'ambito di applicazione.

In relazione al come i principi di integrazione vadano perseguiti, divengono significativi i temi relativi alla trasparenza delle procedure, all'accessibilità dei dati ed alla misura in cui tanto le procedure quanto i dati siano esplicitati all'interno del modello conoscitivo. II problema della trasmissibilità dell'informazione in ambito informatico è oramai tanto pervasivo da aver richiesto una trattazione specifica anche in ambiti apparentemente distanti come quelli della filosofia e dell'etica. In questo contesto, si parla di qualità dell'informazione [Floridi 20। 3] e della possibilità di individuare categorie specifiche in grado di valutarla. Al di là dei contenuti di carattere più generale e della nomenclatura utilizzata, in tale contesto, si pone l'accento sul come l'utilizzo che si fa di un dato o di un'informazione condizioni la sua affidabilità. In altri termini, il potere informativo di qualsiasi elemento varia in relazione all'adeguatezza rispetto al contesto di indagine (fig. I).

La risposta applicativa a questa esigenza collettiva è avvenuta seguendo diversi approcci. La modellazione 3D parametrica basata sui Visual Programming Language (VPL), ad esempio, consente di mantenere traccia di tutte le operazioni condotte sulla forma, sui contenuti e sulle sorgenti dati utilizzate. Riguardo, invece, il tema dell'accessibilità alla banca dati da cui il modello viene prodotto, la questione interseca gli studi relativi alla strutturazione semantica dei contenuti in database. In tal senso, una possibile declinazione della problematica avviene utilizzando proficuamente i sistemi di Building Information Modeling (BIM). A questo scopo,
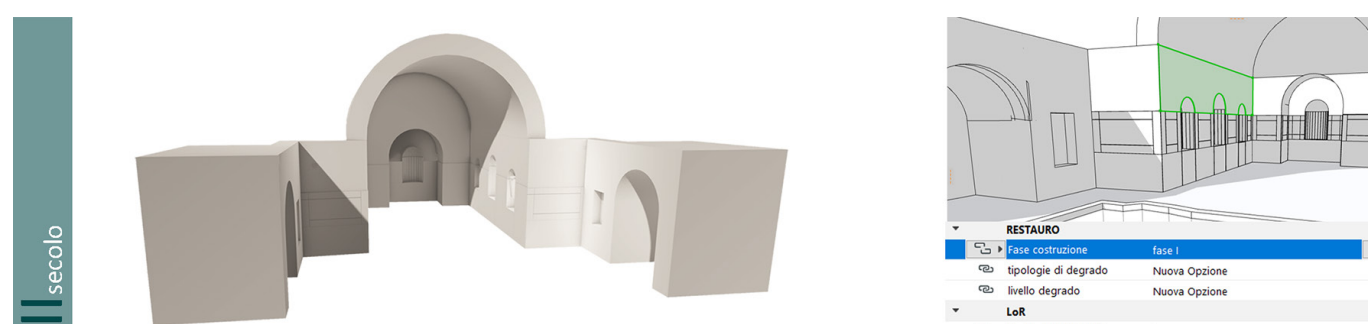

RESTAURO

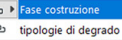

ce) tipologie di degrado Nuvva Opzione

LoR
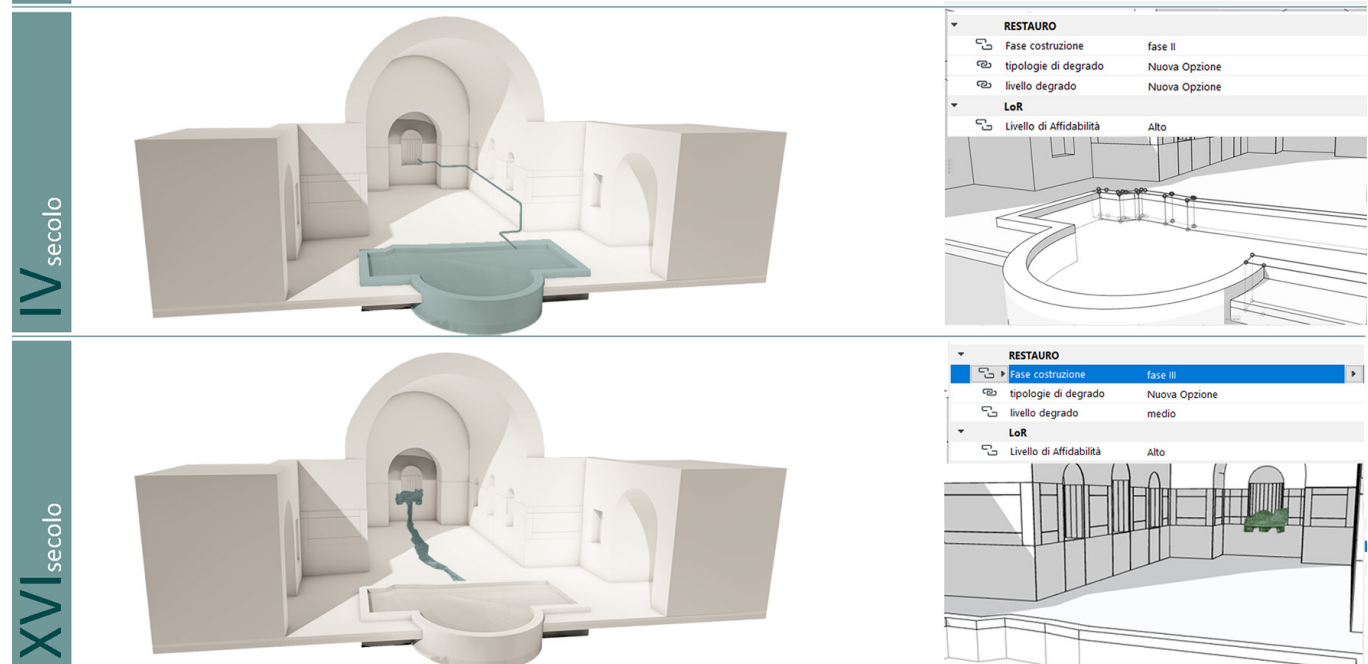

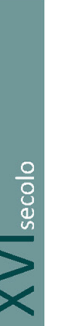
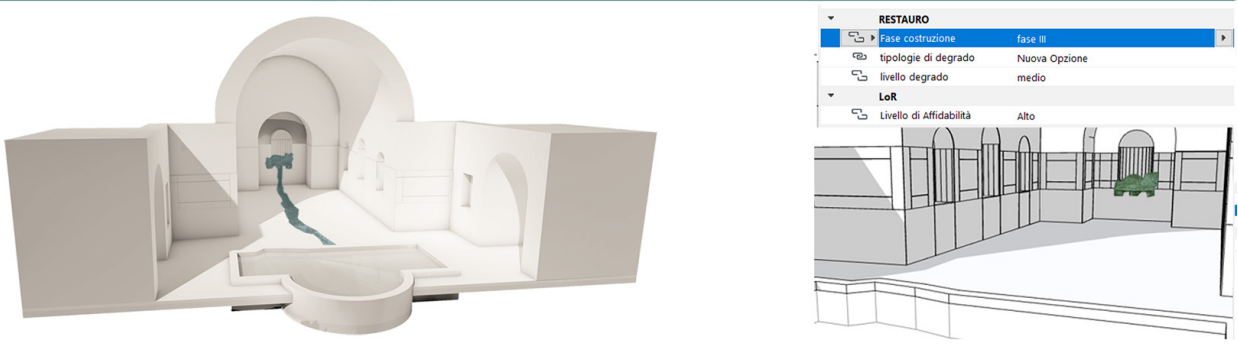
il BIM trova un suo sviluppo nell'implementazione di una serie di funzioni di collegamento tra l'apparato ontologico interno sviluppato rispetto al modello e gli strumenti di codifica semantica standard. I due approcci appena introdotti sono tra loro operativamente interlacciati, ciò definisce un potenziale flusso di lavoro capace di mettere a sistema la possibilità di operare in uno spazio tridimensionale navigabile e parametrico, quella di impostare delle query rispetto ad un database di riferimento e quella di rendere esplicita l'intera procedura di costruzione tanto del modello quando della banca dati a cui si connesso.

Fig. 3. A destra, la nuvola di punti generata tramite processi di SfM a sinistra integrazione con nuvola di punti generata a partire da immagini termografiche [Griffo, Cimadomo, Menconero 2019].

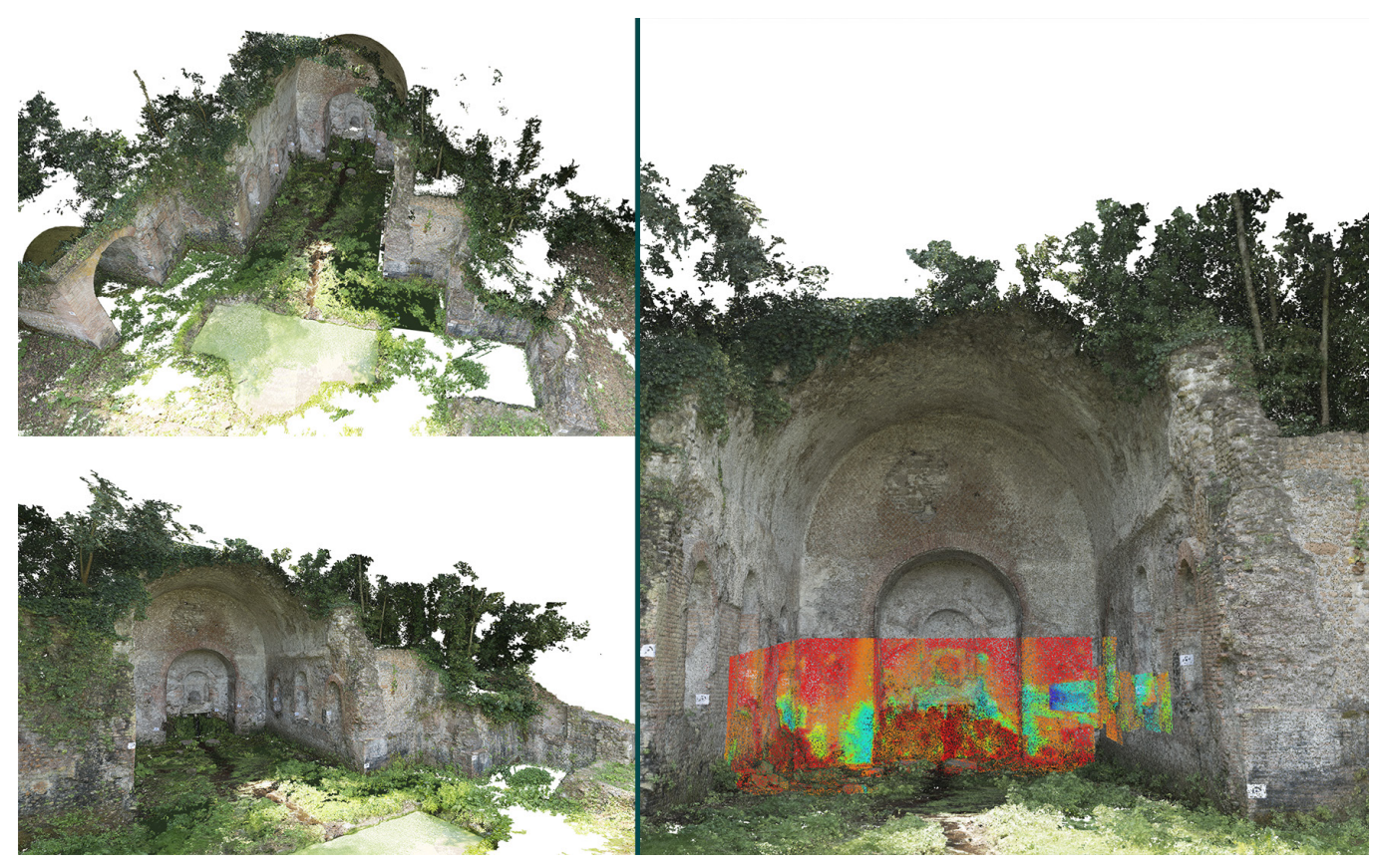

\section{Un'applicazione: il Ninfeo di Egeria}

Lo studio qui presentato sul ninfeo di Egeria ha tracciato un processo di conoscenza sviluppato in più fasi: l'acquisizione dell'apparato documentale di archivio, il rilievo, le indagini diagnostiche, la produzione di modelli. In questa fase verrà approfondito il tema della modellazione e delle strategie di connessione di tutto il sistema di informazioni inerenti all'oggetto. Rispetto al tema della modellazione, il primo ordine di problemi ha interessato le modalità di costruzione e trasmissione delle informazioni delle fasi storiche di utilizzo della struttura. Infatti, l'aspetto, forse, più rappresentativo nel campo dell'architettura archeologica è legato all'interpretazione dell'evoluzione temporale del costruito. In questo senso, l'inclusione di tale panorama informativo arricchisce la conoscenza inerente all'oggetto includendo la funzione del tempo. A tale scopo, per ogni fase costruttiva, sono state individuate le trasformazioni caratteristiche in termini di struttura, funzione e aspetto. Questo primo approccio conoscitivo ha permesso la formalizzazione di un modello stratificato che risponda, in buona sostanza, alla domanda relativa al 'cosa' modellare (fig. 2). Rispetto alla conoscenza dell'oggetto, i caratteri di corrispondenza metrica e morfologica, insieme a quelli relativi alle indagini di tipo diagnostico elaborate sul manufatto [Griffo, Cimadomo, Menconero 2019] (fig. 3), sono stati affidati al modello numerico, quelli invece rappresentativi di una certa lettura, ovvero quelli che costituiscono e definiscono un certo Vorstellung [Ugo I 994, p. I2], il modello concettuale, sono stati elaborati mediante l'approccio parametrico. Partendo da questa prerogativa, gli oggetti modellati sono stati classificati in base alla fase storica, o alle fasi storiche, a cui sono appartenuti (fig. 4). 


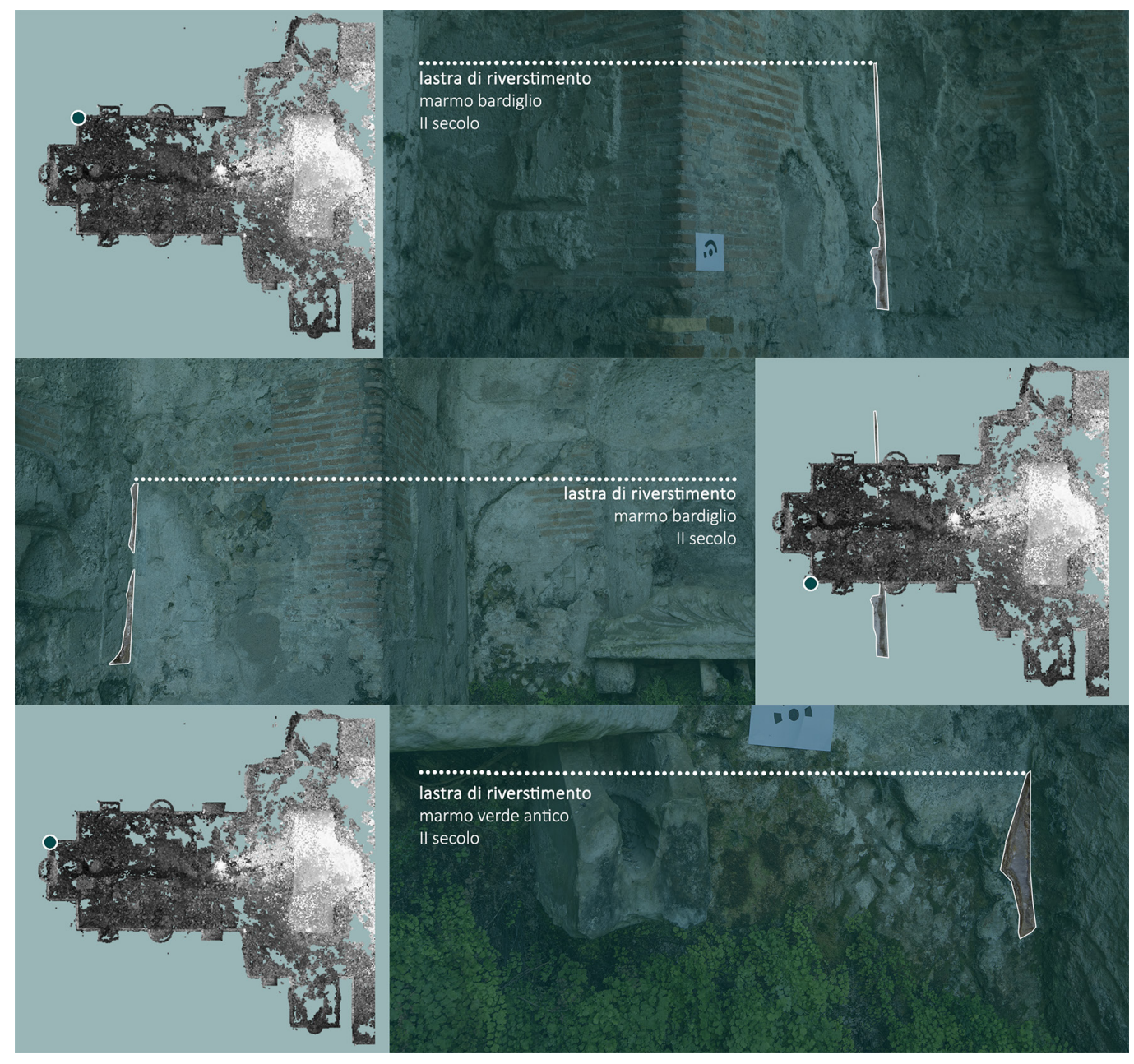

Se fino a questo punto si è tenuto conto delle problematiche legate alla modellazione in ambito BIM, il passaggio successivo riguarda la modellazione dell'informazione, intesa come sviluppo di un sistema di connessioni riferite all'oggetto. II primo interrogativo di carattere metodologico e procedurale ha riguardato l'interazione tra modello numerico e modello parametrico. Le procedure Scan to BIM sono consolidate nell'ambito dell'HBIM e costituiscono una base operativa di gestione dei prodotti del rilievo in un ambiente di modellazione parametrica. La principale problematica riferibile a tale approccio riguarda l'utilizzo della nuvola di punti come una istanza, un oggetto 3D non parametrico e non interrogabile, ad esso ci si riferisce prevalentemente per indagare gli aspetti dimensionali. Questo approccio, in un certo senso, confina il potenziale informativo del modello numerico e lo disconnette rispetto al modello parametrico. La sperimentazione condotta propone un'interazione tra i due modelli basata sull'operazione di semantizzazione applicata al modello numerico. La segmentazione in regioni significative ha, da una parte, aggiunto contenuti informativi già sul modello discreto e, dall'altra, ha reso possibile la parametrizzazione delle regioni prodotte in ambiente BIM. Con tale presupposto, sono state individuate regioni tridimensionali specifiche relative ai lacerti marmorei rinvenuti in loco, alle tracce di intonaco ed a tutti gli elementi rappresentativi per la ricostruzione virtuale dell'oggetto. II criterio di segmentazione adoperato è stato selezionato proprio per 'informare' il modello parametrico grazie ai dati provenienti dal rilievo. In ambiente BIM, gli elementi architettonici modellati e ricostruiti si avvalgono di una connessione logica e spaziale che sostanzia e descrive la scelta formale. Questo processo è stato applicato, ad esempio, all'apparato decorativo murale della fascia orizzontale tra la base delle nicchie e la loro quota d'imposta. La documentazione biblio- 
grafica di riferimento [De Cristofaro 20 I4, p. 36] sembra ricondurre ad una composizione formata da una lastra maggiore, di forma rettangolare o quadrangolare, posta al centro dell'interstizio tra le due nicchie o tra la nicchia e il termine della parete. Questi dati sono stati un riferimento utile all'individuazione in situ dei lacerti di marmo verde antico; i lacerti sono stati documentati tramite il rilievo, individuati sul modello numerico, selezionati e segmentati rispetto al resto della nuvola di punti. La regione così prodotta è stata importata in ambiente parametrico e connessa all'elemento modellato corrispondente. L'elemento parametrico della pannellatura marmorea descrive la forma, le dimensioni e la consistenza materica secondo l'ipotesi ricostruttiva, le fonti di supporto all'ipotesi sono tutte rese esplicite ed interrogabili sotto la forma di parametri dell'elemento (figg. 5, 6).

Questo stesso approccio è stato utilizzato per l'intero apparato decorativo, il modello proposto racconta l'edificio considerando il suo presente, tramite i modelli numerici, ed i suoi passati.

In dipendenza dalla quantità e dalla tipologia di documentazione di partenza disponibile per ogni elemento, è stato possibile individuare tre classi di affidabilità per la ricostruzione di ogni elemento: il livello più alto di affidabilità corrisponde alla condizione in cui l'elemento è ancora visibile in situ in maniera significativa, la sua consistenza è acquisita mediante il rilievo e documentata da fonti iconografiche; il livello medio comprende i componenti modellati prevalentemente a partire da descrizioni presenti nelle fonti e la cui consistenza è solo parzialmente ancora visibile in situ; il livello basso di affidabilità corrisponde ad una ipotesi di modellazione basata su confronti rispetto a componenti analoghe per periodo ed area territoriale (fig. 7).
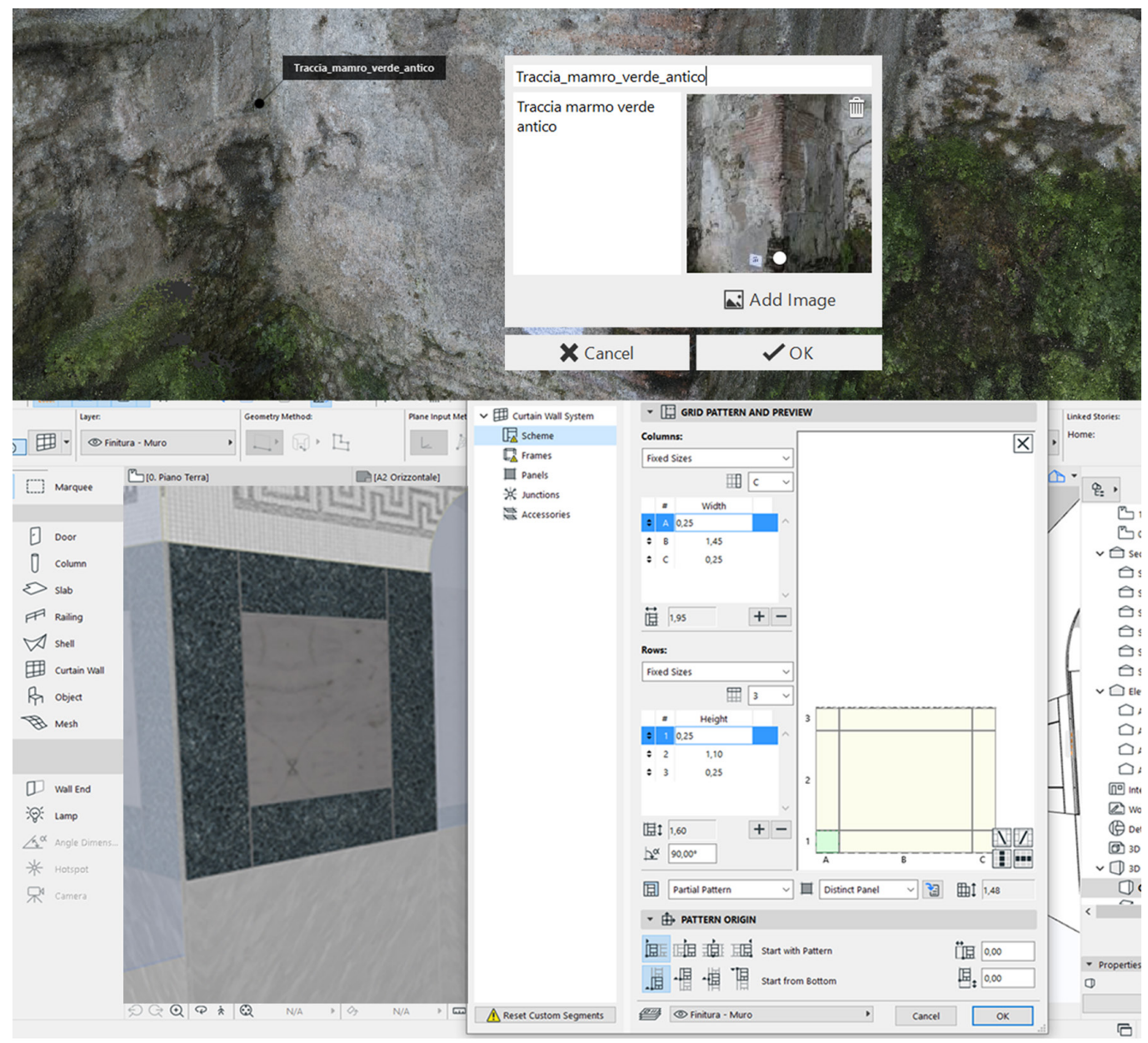
L'impostazione proposta ben si presta a ripercorrere graficamente la ricerca sul manufatto, il tema dell'affidabilità del modello è ripostulato rispetto allo studio storico e archeologico. La ricostruzione tridimensionale proposta percorre, in realtà, solo una delle ipotesi storiografiche formulate sul ninfeo, la possibilità di riferirsi a dei livelli di affidabilità, unita a quella di poter interagire con le differenti fasi di costruzione dell'oggetto, apre uno scenario in cui, potenzialmente, ogni ipotesi ricostruttiva trova spazio in una versione del modello visualizzabile ed interrogabile mediante il filtraggio delle informazioni, a ciascuna versione è connesso l'apparato documentale che l'ha generata, non si tratterà, dunque, di tanti modelli ricostruttivi bensì di un unico modello strutturato in cui convivono, dialogando, le diverse ricerche condotte sul tema (fig. 8).

\section{Conclusioni}

A distanza di anni dalle prime sperimentazioni BIM sul patrimonio costruito ed a distanza di qualche decennio dalle prime sperimentazioni sulle possibili integrazioni di nuvole di punti, il tema del connubio tra questi due insiemi è ancora lontano dell'essersi esaurito. Al contrario, il dibattito ha oggi trovato nuovo vigore proprio a causa dell'estrema facilità con cui dati e informazioni vengono generati ed immessi nel mondo digitale. Ė proprio in ragione di tale sovrabbondanza che studi relativi alla semantica, alle ontologie e, più in generale, all'epistemologia, hanno sperimentato un'estensione della loro sfera d'azione includendo in maniera consistente, i campi di indagine relativi alle tecnologie per l'informazione.

In questo quadro, nella ricerca presentata, vanno delineandosi due diverse tendenze, da una parte si scorge la necessità di approcciare la conoscenza dell'oggetto integrando e fondendo un numero sempre crescente di dati, ciascuno relativo ad una proprietà; su questa linea,
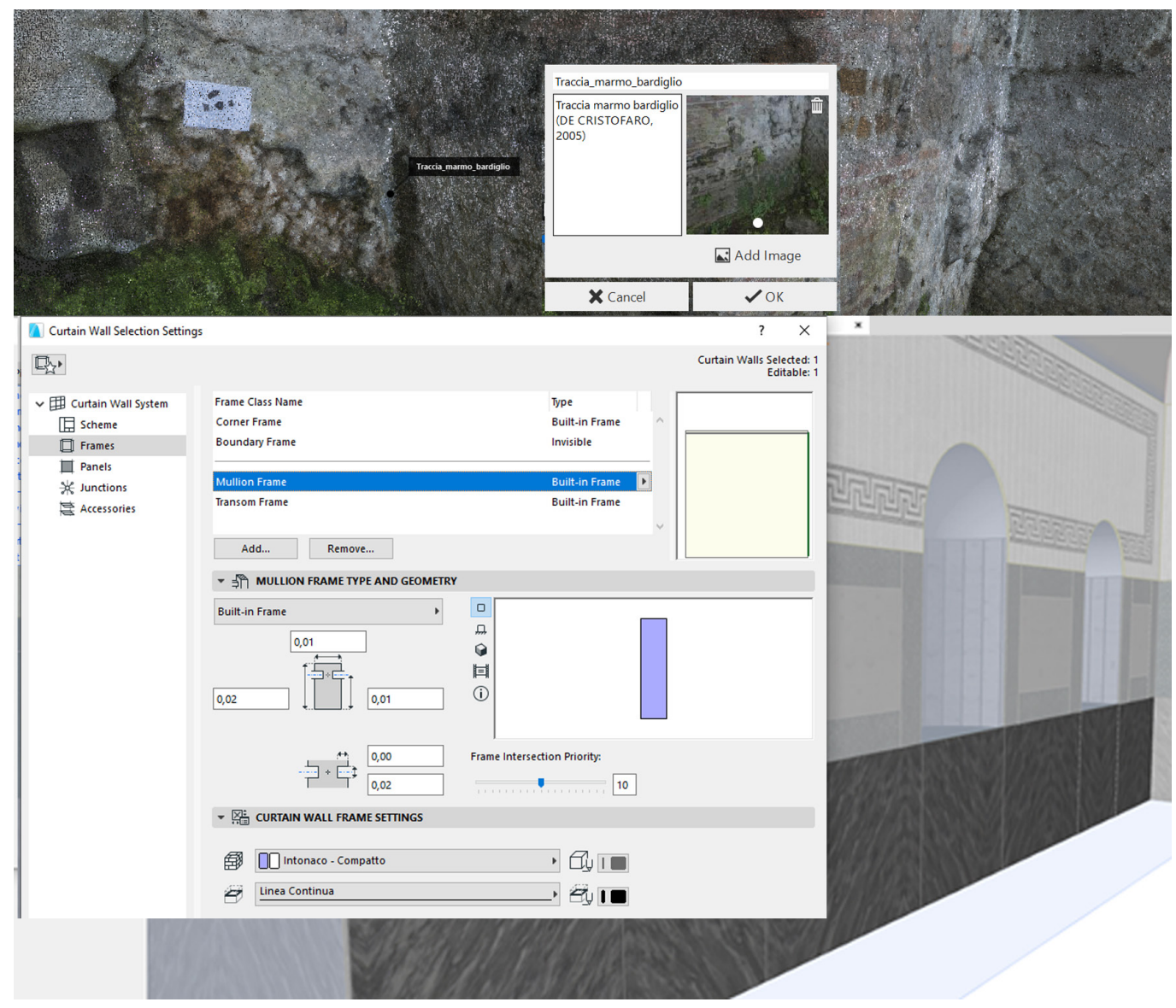
il prodotto è un modello generale. Su questo filone, si inseriscono i processi di data fusion, declinati rispetto a diversi livelli di fusione e trasversali rispetto a diversi ambiti di ricerca. Dall'altra parte, pare evidente la necessità di restringere il campo di indagine per approfondire un unico aspetto dell'oggetto e costruire, a partire da esso, modelli interpretativi altamente specialistici. Tra questi due diversi approcci, la ricerca presentata si propone di sottolineare un certo rapporto di circolarità; i modelli discreti generati da processi di data fusion e segmentazione di nuvole di punti si predispongono come strumenti di analisi dotati di una propria autonomia, allo stesso modo, i modelli continui e parametrici favoriscono il processo di analisi direzionando, in un certo senso, lo sguardo del ricercatore. La possibilità di disporre in un ambiente virtuale unico tanto dei primi quanto dei secondi, è necessaria al trasferimento dell'intero impalcato conoscitivo. II modello così inteso è generato dai collegamenti che è possibile pensare e costruire tra le diverse sorgenti informative, questi collegamenti rappresentano l'infrastruttura digitale di supporto alla comprensione. Ogni sinapsi digitale attivata permette il passaggio tra spazi virtuali diversi in cui, di volta in volta, la lettura del modello si trasforma, cambia punto di vista e risponde a nuovi interrogativi.
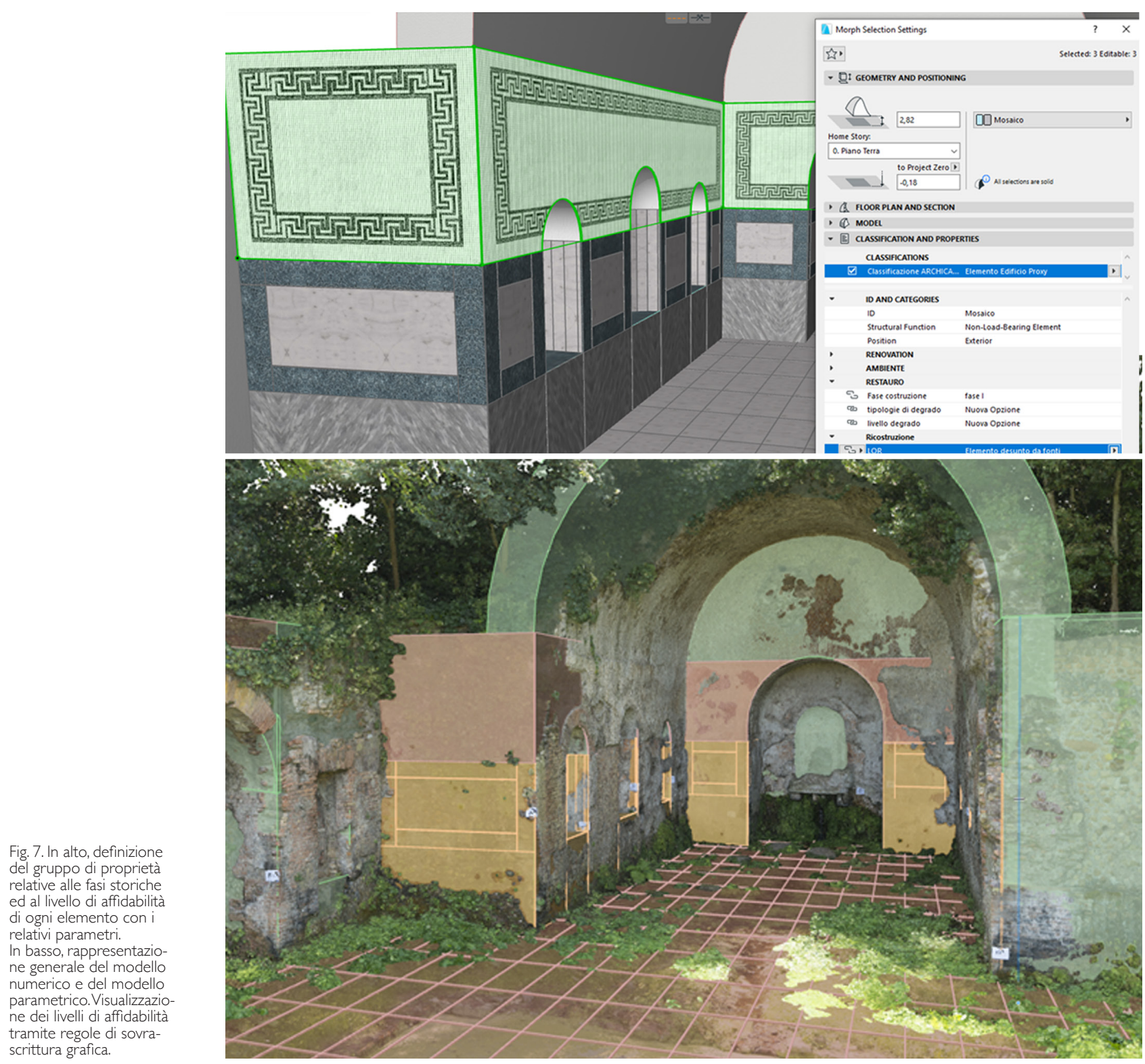


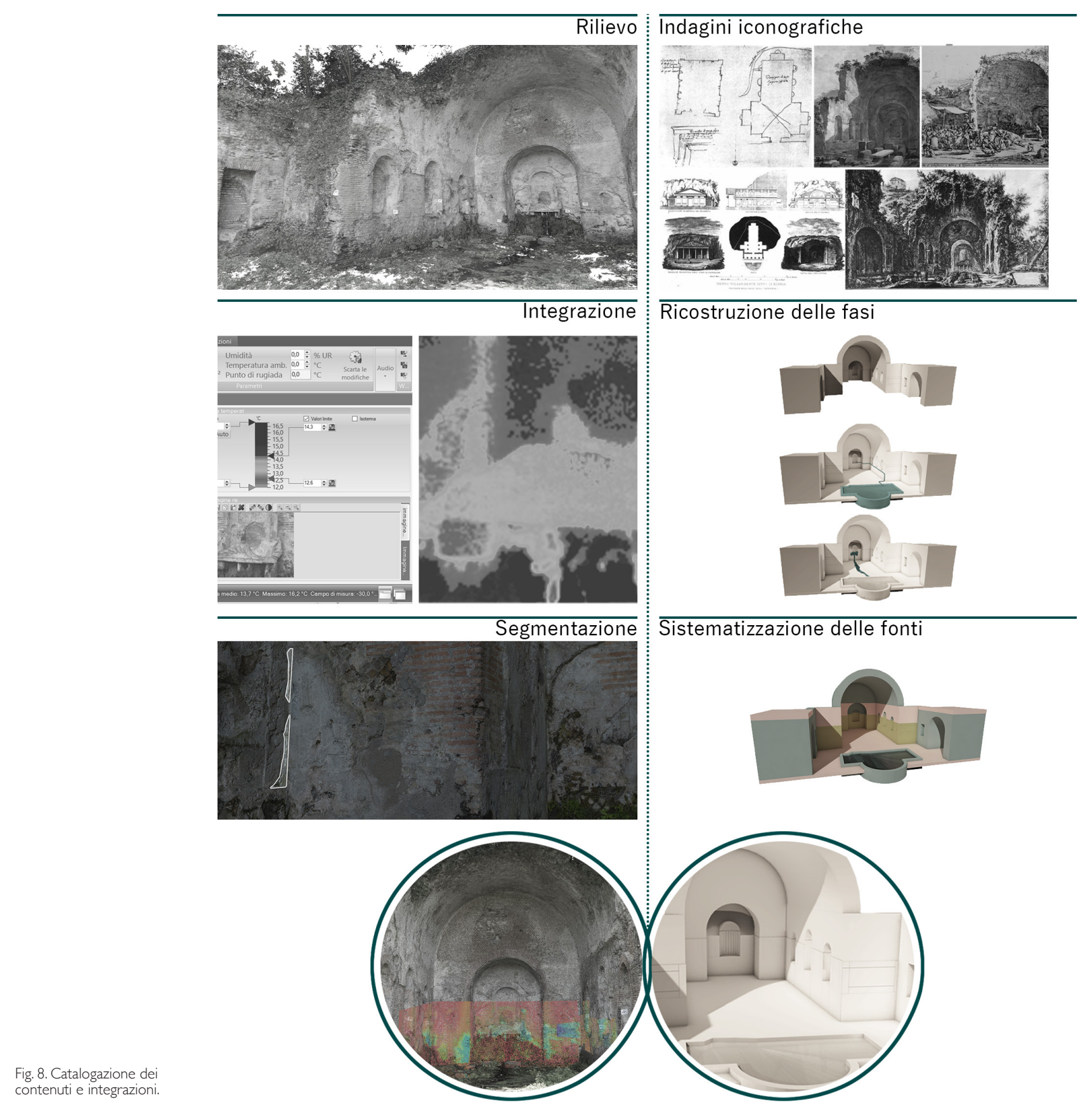




\section{Riferimenti bibliografici}

Ackoff Russell (1989). From data to wisdom. In Journal of Applied Systems Analysis, 16, 1989, pp. 3-9.

Apollonio Fabrizio Ivan (2015). Classification schemes and model validation of 3D digital reconstruction process. In Wolfgang Börner, Uhlirz Susanne (eds.). 20th International Conference on Cultural Heritage and New Technologies.Vienna: Museen der Stadt Wien - Stadtarchäologie, pp. I- I I.

Bianchini Carlo (20I2). La documentazione dei teatri antichi del mediterraneo. Roma: Gangemi Editore.

Bianchini Carlo, Nicastro Saverio (2018). The definition of the Level of Reliability: a contribution to the transparency of Historical-BIM processes. In Dn. Building Information Modeling, Data \& Semantics, 2, 2018 , pp. 46-59.

Boström Henrik, Andler Sten, Brohede Marcus, Johansson Ronnie, Karlsson Alexander, Laere Joeri, Niklasson Lars, Klingegård Maria, Persson Anne, Ziemke Tom (2007). On the definition of information fusion as a field of research. In Tech Report, HS-IKITR-07-006, pp. I-8

Calvano Michele (2019). Disegno Digitale Esplicito. Processi digitali per la rappresentazione della città, l'architettura, il prodotto, Ariccia: Aracne Editrice.

De Cristofaro Alessio (20 I4). II Ninfeo di Egeria nella valle della Caffarella a Roma. Forma, cronologia, funzione. In Orizzonti, $\mathrm{XV}, 20 \mid 4$, pp. 3I-49.

Floridi Luciano (20 I 3). Information Quality. In Philosophy \& Technology, 26, 20 I 3, pp I-6.

Griffo Marika, Cimadomo Paolo, Menconero Sofia (2019). Integrative IRT for documentation and interpretation of archaeological structures. In Int. Arch. Photogramm. Remote Sens. Spatial Inf. Sci., XLII-2/WI 5, 20 I 9, pp. 533-539.

Khaleghi Bahador, Khamis Alaa, Karray Fakhreddine O., Razavi Saiedeh N. (20I3). Multisensor data fusion: A review of the stateof-the-art. In Information Fusion, I4, 2013 , pp. 28-44.

Lahat Dana, Adali Tulay, Jutten Christian (2015). Multimodal Data Fusion: An Overview of Methods, Challenges, and Prospects In Proceedings of the IEEE, I03, 2015, pp.1449-1477.

Ugo Vittorio (1994). Fondamenti della rappresentazione architettonica. Bologna: Società editrice Esculapio.

Autori

Carlo Bianchini, Sapienza Università di Roma, carlo.bianchini@uniroma L.it

Marika Griffo, Sapienza Università di Roma, marika.griffo@uniromal.it

Per citare questo capitolo: Bianchini Carlo, Griffo Marika (2020). Digital synapsis: dati, informazioni e modelli in connessione/Digital synapsis: data, information, models in connection. In Arena A., Arena M., Brandolino R.G., Colistra D., Ginex G., Mediati D., Nucifora S., Raffa P. (a cura di). Connettere. Un disegno per annodare e tessere. Atti del $42^{\circ}$ Convegno Internazionale dei Docenti delle Discipline della Rappresentazione/Connecting. Drawing for weaving relationships. Proceedings of the 42th International Conference of Representation Disciplines Teachers. Milano: FrancoAngeli, pp. 1740-1759. 


\title{
Digital Synapsis: Data, Information, Models in Connection
}

\author{
Carlo Bianchini \\ Marika Griffo
}

Abstract

In the digital environment, the technological revolution allowed a rapid growing and a remarkable development of deeply different interpretative models. This process encouraged the spread of data and information in terms of divulgation as well as dissemination. In the meantime, this revolution has generated a superabundance of them that makes difficult to distinguish the meaningful data among what is not (the so-called background noise). The research here presented intends to focus on integration processes of typologically different data in the digital word and how the informatic structure could affect their use. Field of application is the built cultural heritage. The main goal is to set up a methodology of investigation that could promote a continuity of process between products of knowledge derived from a discretization of reality and those generated from interpretative processes.

Keywords

conceptual model, survey, Building Information Model, Level of Reliability, data integration.

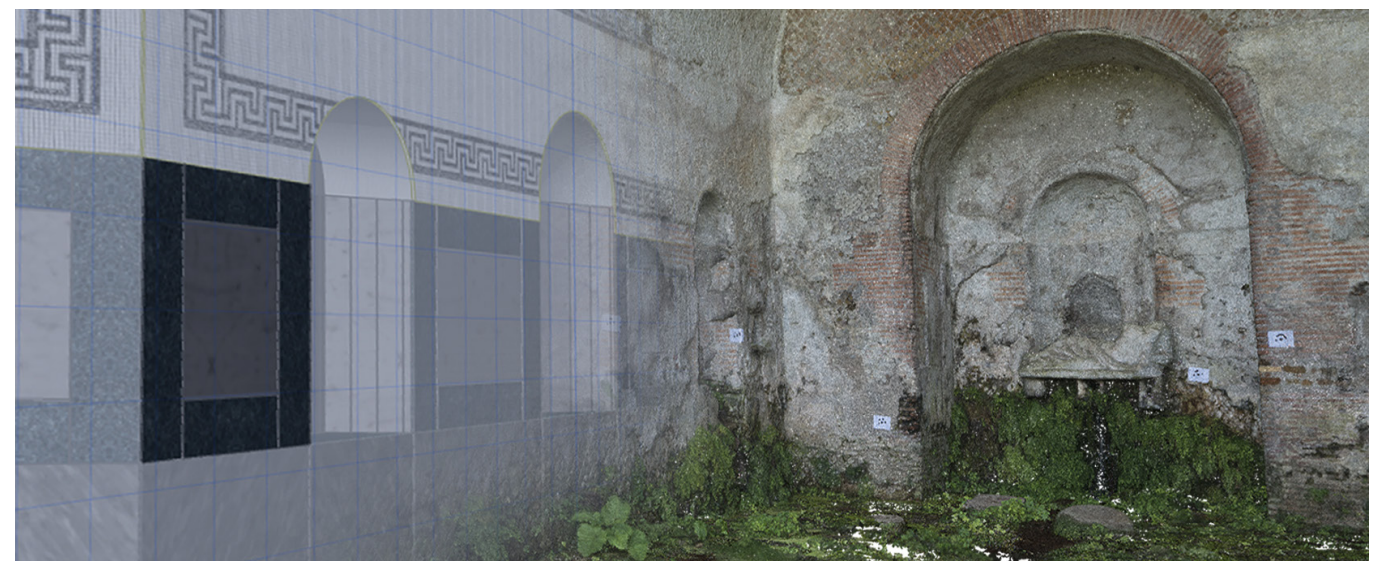




\section{Digital intersections: knowledge as a complex system}

The entropy of virtual three-dimensional space seems to be inexorable. The creation of digital clones seems to be the only effective precaution to ensure that, in the future, there will be trace of the real world as we know it. Facing this perspective, it is evident the necessity of composing menage systems of data that would give the order to the current production and that would ensure a future intelligibility of them.

The field of representation of built cultural heritage needs to investigate the possibilities of interaction $\mathrm{h}$ heterogeneous data into digital model

This approach entrusts on a principal of complementarity of knowledge processes finalized to the convergency, in the virtual environment. Of different field of research.

Every virtual space of every field of research is populated by data, they become more and more complex by aggregate themselves becoming information and them models.

These models are built selection and processing only few qualities of the object. Starting from statistical predictive model to the diagnostic, structural, geometric ones, each process of knowledge has an its own methodological and procedural autonomy. Integration among these components may occur by identifying a virtual space that is suitable to host data, information, and models very different among them and that would be able to explicit the singular characteristics of each field of research.

In general terms, distinction between data, information and knowledge is investigate by the Information Science to define grades of complexity and development that participate to cognitive processes [Ackoff 1989].

Although in each specific sector these levels have assumed different names and sometimes quite specific meanings, it is still possible to describe the common characteristics that fits to various fields. The organization of cognitive processes is applicable to the documentation and transmission of the built heritage and takes on particular significance with reference to the issue of integrating heterogeneous data. Specifically, everything that describes the properties of the architectural work without specific connotations can be assimilated to data, it is the input, what is entered into the system to activate it. The information instead refers to the interpretation with respect to the context, the data is processed and transformed to take on a meaning. With reference to the next level of development, the one linked to knowledge, it is possible to read a specificity related to the field of representation of architecture. In it, knowledge finds its configuration through the model. Knowledge of the object is the model that the scholar produces of it.

Fig. I. Theo Kamecke, Az-Tech. 24 carat gold circuits produced in the 60s. The depowering of information: the electronic circuit is one of the most iconic symbols of digital information, its decontextualized use depower its primary role to give it another.

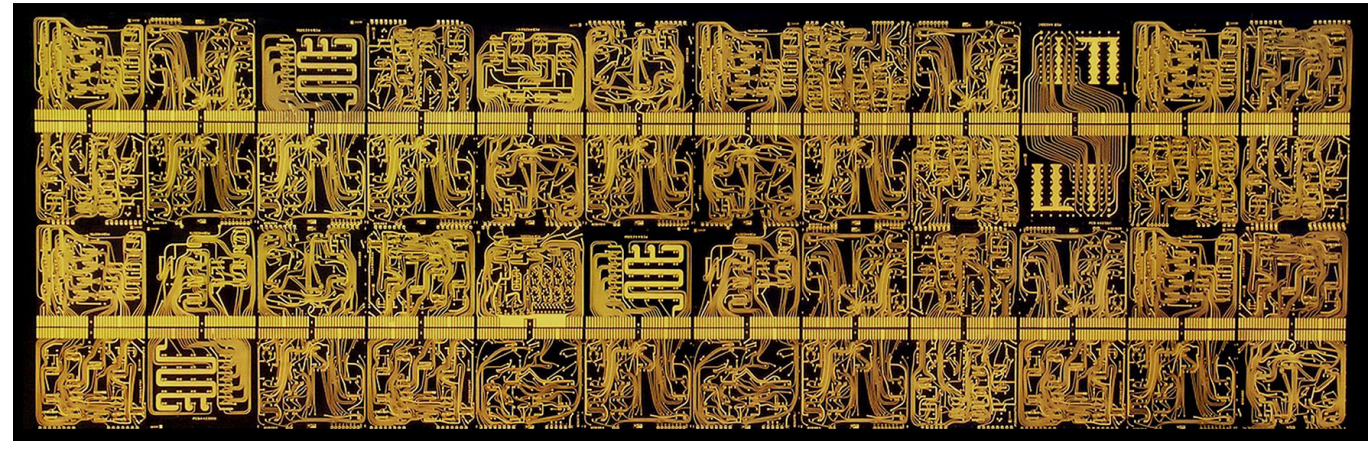

\section{Integration: open issues}

The image of the model as a thematic representation of reality has been outlined so far insisting on a conceptual and, in some ways, autonomous point of view with respect to the ways and tools that can be used. The next step leads to the question of whether a certain level of methodological (ways) and technological (tools) awareness can enhance the roles of the model and give it new ones. 
The why of the integrations finds its root in the programmatic need to reach 'deep knowledge' of the object. Having the ability to access disparate descriptive factors, the object assumes its own configuration by which each data that is inserted into the system changes the whole model and contributes to a wider understanding. Each method of investigation reports a diversity, that is an added value. It is complementary to the others and allows the generation of logical and conceptual constraints necessary to understand the object. The concept of integrated analysis is innate for human beings, we are used to experiencing reality by easily combining our sensors, or our senses, and knowing the external world through them; it is from this perspective that the ever-growing development of data fusion studies takes on a leading role.

In relation to the how the integration principles are to be pursued, it becomes significant the issues relating to the transparency of procedures, the accessibility of data and the extent to which both the procedures and the data are explicit within the cognitive model. The problem of information transmission in the IT field is now so pervasive that it has required specific attention even in some apparently distant fields such as philosophy and ethics. In this context, we speak of information quality [Floridi 20 I3] and the possibility of identifying specific categories capable of evaluating it. Beyond the more general content and the nomenclature used, in this context, the emphasis is placed on how the use that is made of each single data or information affects its reliability. In other words, the information power of any element varies in relation to the adequacy to the context of the investigation (fig. I). An applicative answer to this collective need was made by following different approaches. Parametric 3D modeling based on Visual Programming Languages (VPL), for example, allows one to keep track of all the operations carried out on the shape, content and data sources used to generate the model. Regarding, however, the issue of accessibility to the database from which the model is produced, the question intersects the studies relating to the semantic structuring of the contents in the database. In this sense, a possible declination of the problem occurs by profitably using the Building Information Modeling (BIM) systems. For this purpose, BIM finds its development in the implementation of a series of link fun-
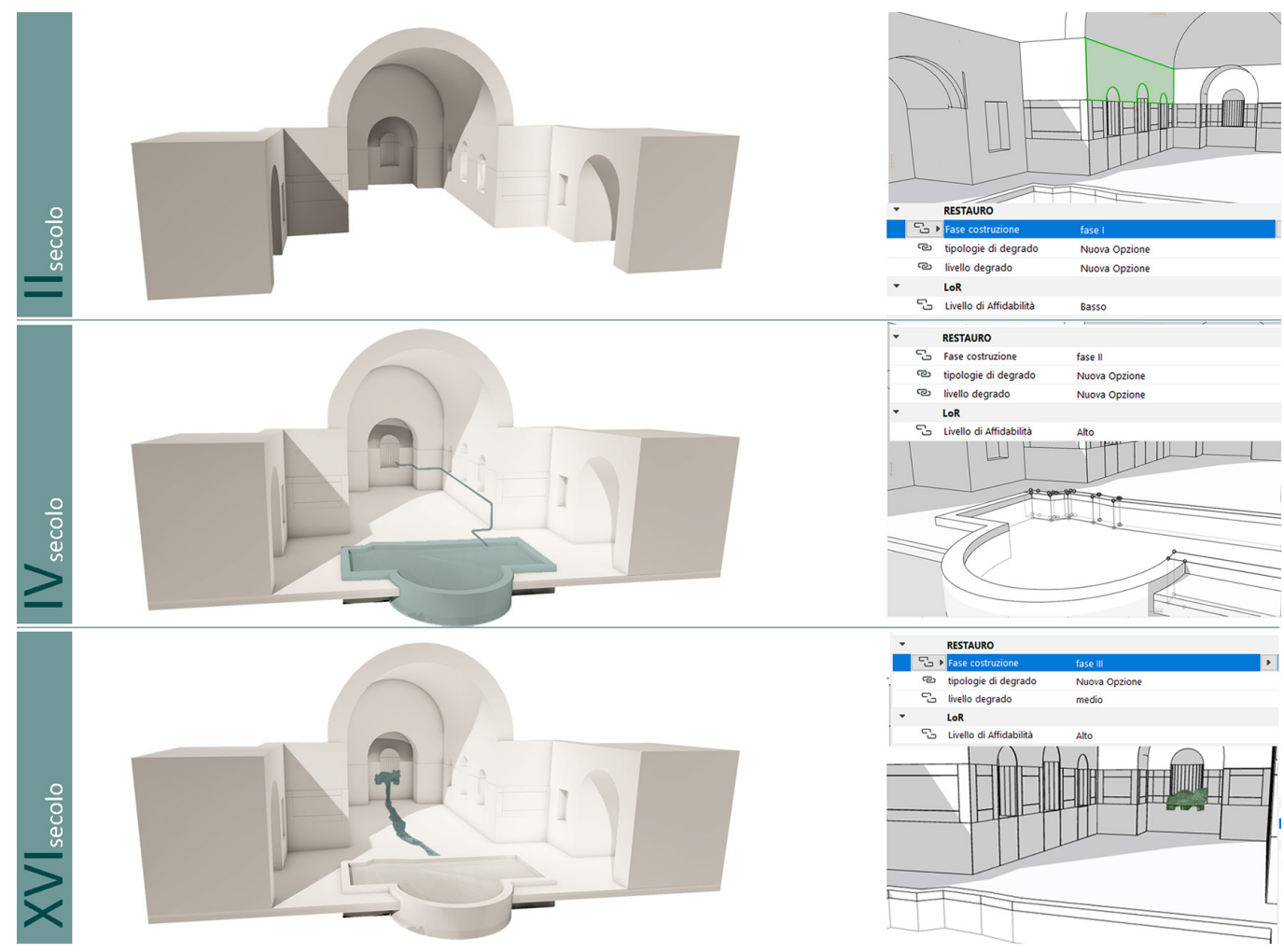
RESTAURO ? Fase costruzione (e) tipologie di degrado Nuvva Opzione LoR

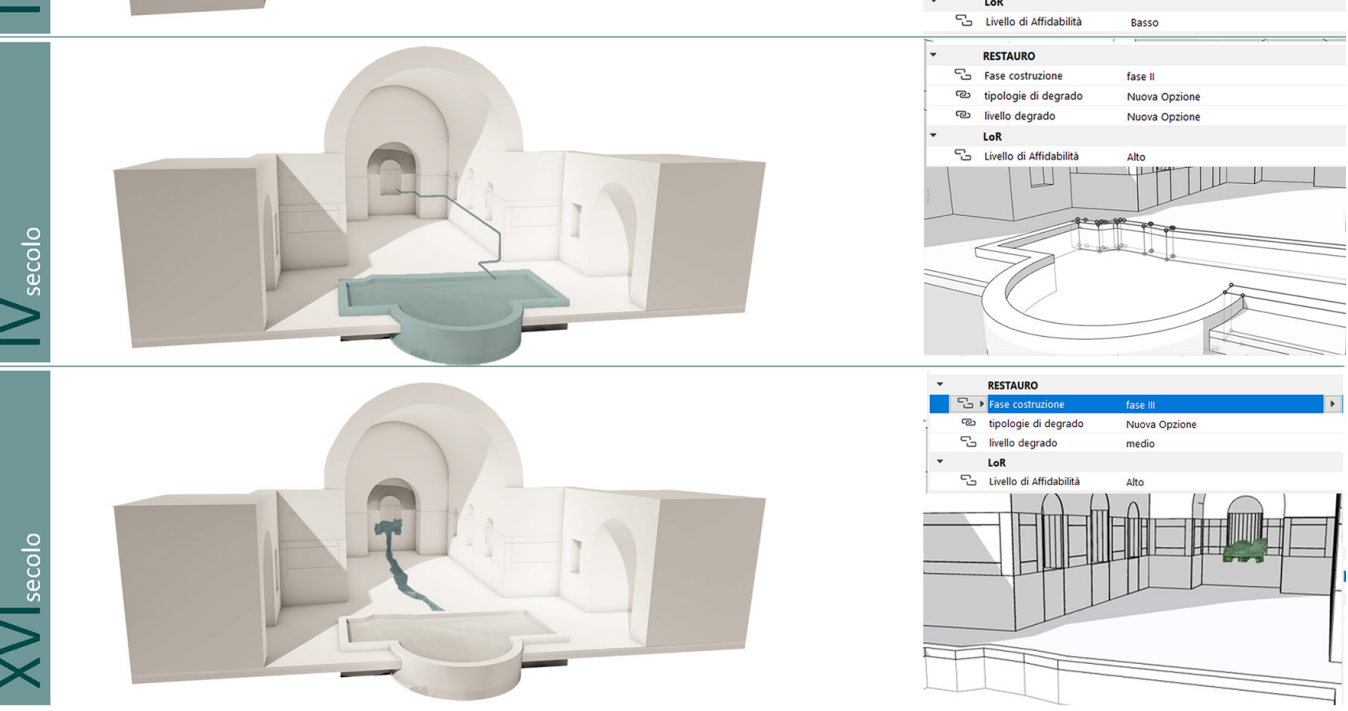


ctions between the internal ontological apparatus developed with respect to the model and the standard semantic coding tools. The two approaches just introduced are operationally interlaced with each other, this defines a potential workflow capable of systematising the operations in a navigable and parametric three-dimensional space. In addition, the process allows setting queries with respect to a reference database and making it explicit the whole construction procedure of the model and of the database to which it is connected.

Fig. 3. On the right, the point cloud generated by SFM processes, on the left, integration with point cloud generated from thermographic images [Griffo, Cimadomo, Menconero 2019].

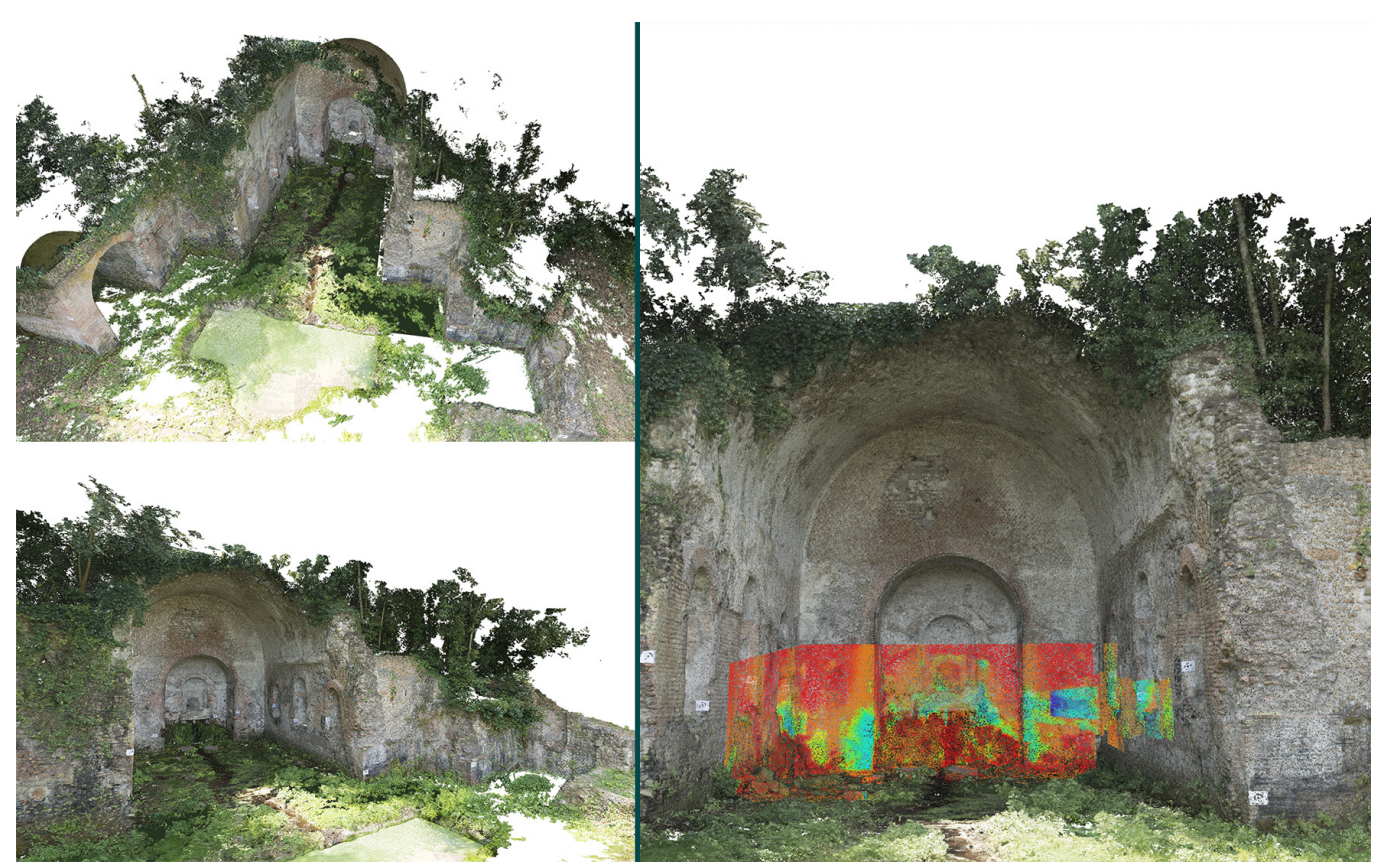

\section{An application: the nymphaeum of Egeria}

The study here presented on the nymphaeum of Egeria traced a knowledge process developed in several phases: the acquisition of the archive documental apparatus, the survey, the diagnostic investigations, the production of models. The focus here is on modeling approaches and the strategies of connection of the whole system of information inherent to the object. With respect to the theme of modelling, the first order of problems concerned methods to construct and transmit information of the historical phases of the structure. In fact, perhaps, the most representative aspect in the field of archaeological architecture is linked to the interpretation of the temporal evolution of the built structure. In this sense, the inclusion of this information panorama enriches the knowledge inherent to the object by including the function of time. For each construction phase, the characteristic transformations in terms of structure, function and appearance have been identified.This first cognitive approach has allowed the formalization of a stratified model that responds, in essence, to the question of what to model (fig. 2). With respect to the knowledge of the object, the characters of metric and morphological correspondence, together with those related to the diagnostic type investigations elaborated on the artefact [Griffo, Cimadomo, Menconero 20 I9] (fig. 3), have been demanded to the numerical model, those instead representative of a certain reading, i.e. those that constitute and define a certain Vorstellung [Ugo | 994, p. I 2] the conceptual model, have been elaborated through the parametric approach. Starting from this prerogative, the modelled objects have been classified according to the historical phase, or historical phases, to which they belonged (fig. 4). 


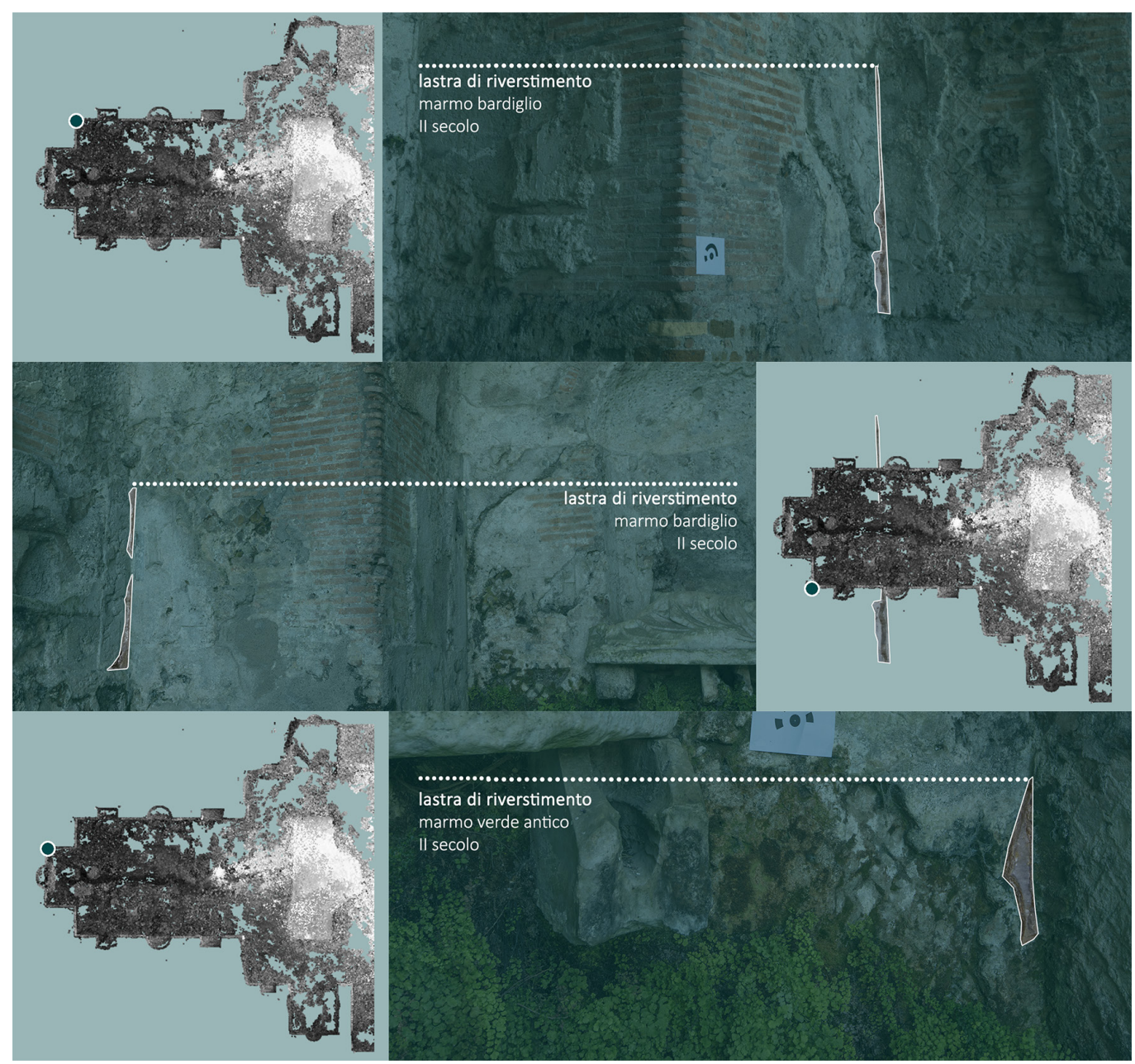

If up to this point the problems related to the modelling in the BIM field have been taken into account, the next step concerns the modelling of the information, as a system of connections referred to the object. The first question of methodological and procedural character has concerned the interaction between numerical model and parametric model. The Scan to BIM procedures is consolidated within HBIM and constitute an operational basis for the management of the survey products in a parametric modeling environment. The main problem related to this approach concerns the use of the point cloud as an instance, a non-parametric and blocked 3D object, mainly referred to it to investigate dimensional aspects. This approach, in a certain sense, confines the informative potential of the numerical model and disconnects it from the parametric model. The experimentation here conducted proposes an interaction between the two models based on the operation of semantization applied to the numerical model. The segmentation into significant regions has, on the one hand, added information content already on the discrete model and, on the other hand, has made possible the parameterization of the regions produced in the BIM environment. With this assumption, specific three-dimensional regions have been identified related to the marble fragments found in situ, to the traces of plaster and to all the representative elements for the virtual reconstruction of the object. The segmentation criterion has been selected to inform the parametric model thanks to the data from the survey. In the BIM environment, the modeled and reconstructed architectural elements make use of a logical and spatial connection that substantiates and describes the formal choice. This process has been applied, for example, to the wall decoration of the horizontal band between the base of the niches and their height. The reference bibliographic documentation [De Cristofaro 20 I4, p. 36] seems to lead 
back to a composition formed by a major slab, rectangular or quadrangular in shape, placed at the centre of the interstice between the two niches or between the niche and the end of the wall.These data were a useful reference for the in situ identification of the ancient green marble fragments; the fragments were documented through the survey, identified on the numerical model, selected and segmented with respect to the rest of the point cloud. The region thus produced was imported into a parametric environment and connected to the corresponding modeled element. The parametric element of the marble panelling describes the shape, dimensions, and material consistency according to the reconstructive hypothesis, the sources of support to the hypothesis are all made explicit and questionable in the form of parameters of the element (figs. 5, 6).

This same approach has been used for the entire decorative apparatus, the proposed model recounts the building considering its present, through numerical models, and its past.

Depending on the quantity and the type of documentation available for each element, it was possible to identify three classes of reliability for the reconstruction of each element: the highest level of reliability corresponds to the condition in which the element is still significantly visible in situ, its consistency is acquired through the survey and documented by iconographic sources; the average level includes the components modelled mainly from descriptions present in the sources and whose consistency is only partially still visible in situ; the low level of reliability corresponds to a modelling hypothesis based on comparisons with similar components by period and territorial area (fig. 7).

The proposed approach lends itself well to graphically retrace the research on the artefact, the theme of model reliability is re-postulated with respect to the historical and archaeological study.
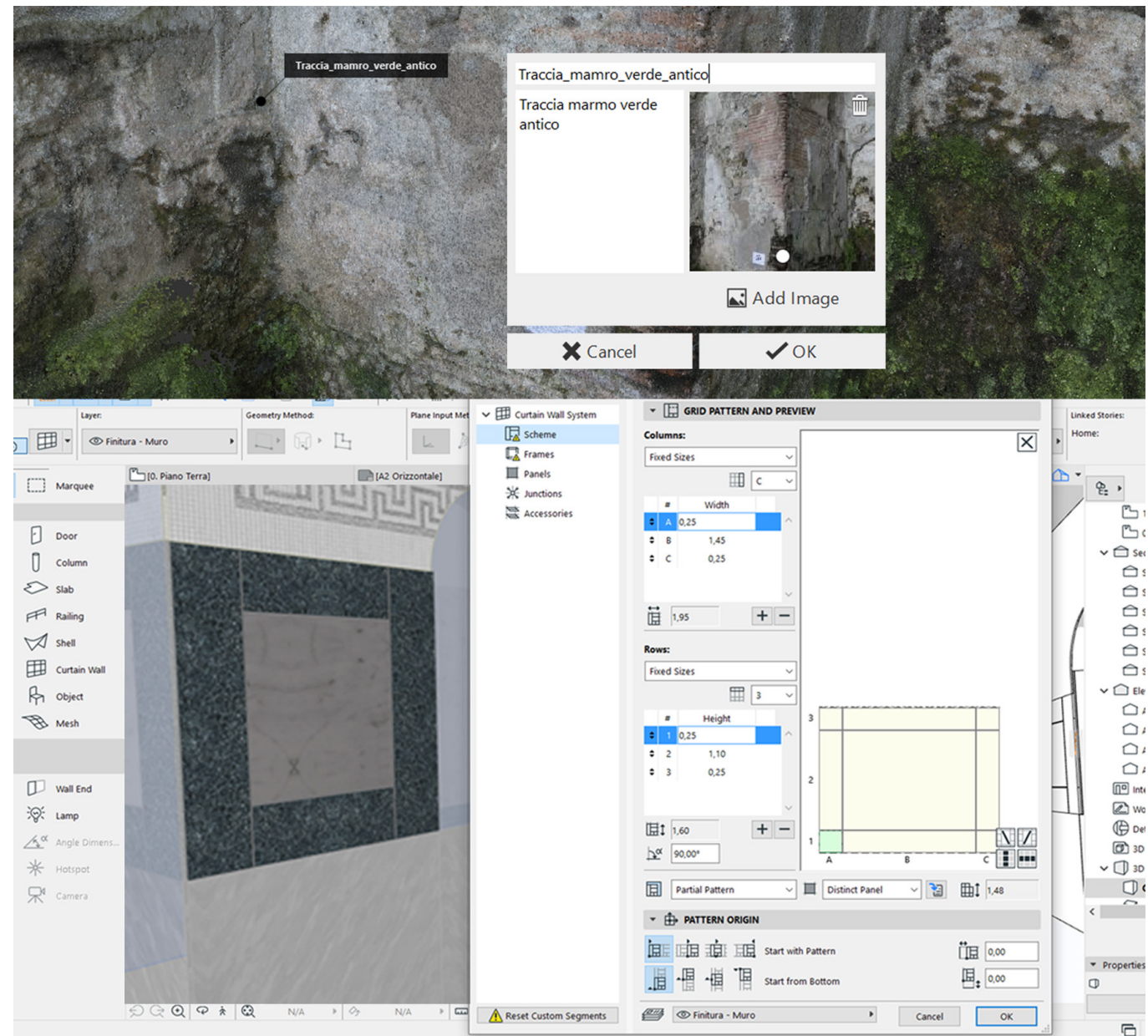
The three-dimensional reconstruction proposed covers only one of the historiographical hypothesis formulated on the nymphaeum, the possibility of referring to levels of reliability, together with that of being able to interact with the different phases of construction of the object, opens a scenario in which, potentially, Each reconstructive hypothesis finds its place in a version of the model that can be visualized and interrogated through the filtering of information; the documental apparatus that generated it is connected to each version, therefore, will not be many reconstructive models, but a single structured model in which the different researches carried out on the subject coexist, dialoguing (fig. 8).

\section{Conclusions}

After several years from the first BIM experimentations on the built heritage and few decades after the first experimentations on the possible integrations of point clouds, the theme of the union between these two sets is still far from being exhausted. On the contrary, the debate has today found new vigour precisely because of the extreme ease with which data and information are generated and introduced into the digital world. It is precisely because of this overabundance that studies relating to semantics, ontologies and, more generally, epistemology, have experimented with an extension of their sphere of action to include information technology fields of investigation.

In this framework, in the research presented, two different trends are emerging, on the one hand we can see the need to approach the knowledge of the object by integrating and merging an increasing number of data, each related to a property; on this line, the product is a general model. On this line, the product is a general model. On this line, data fusion processes are inserted, declined with respect to different levels of fusion and transversal with
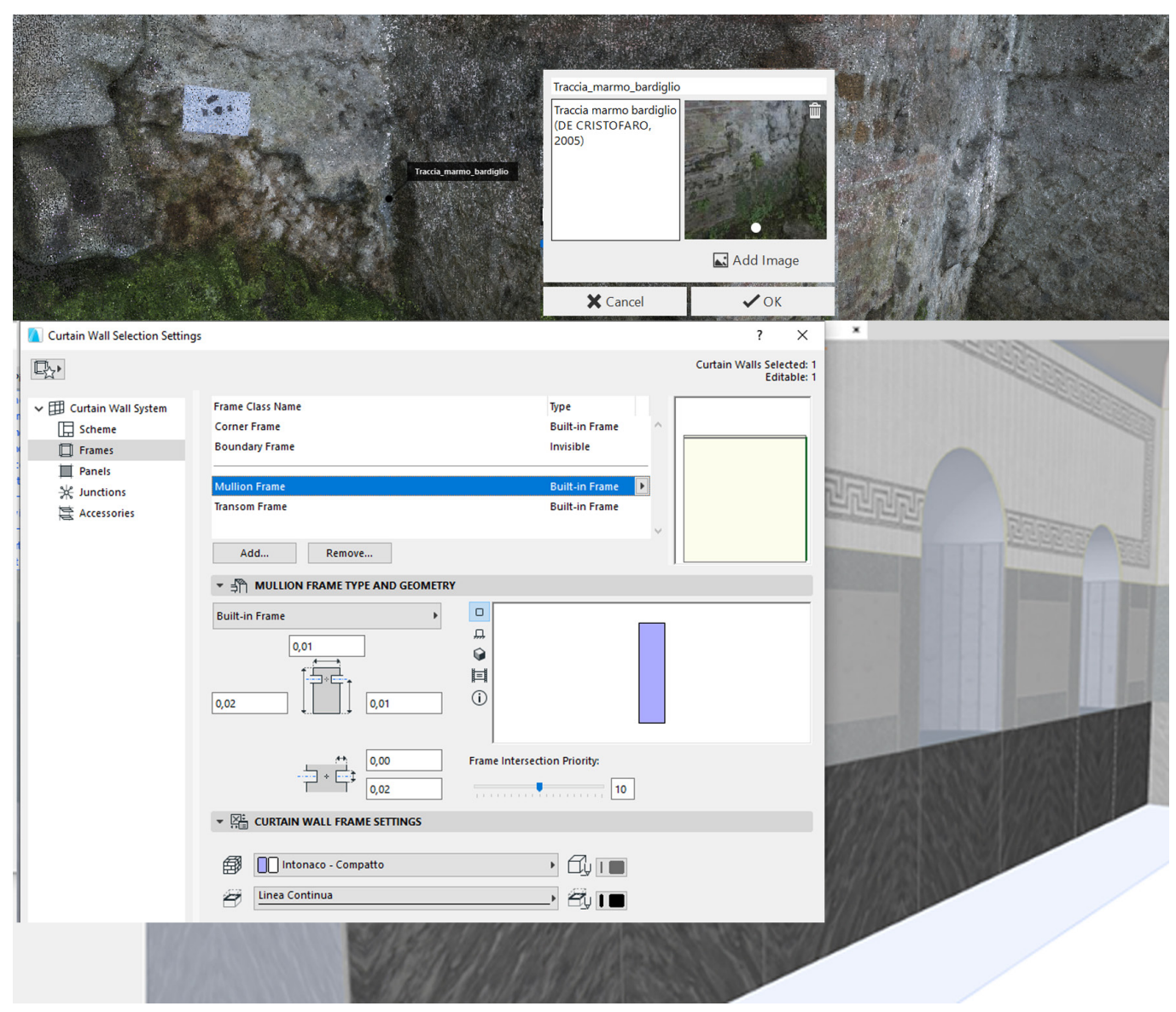
respect to different areas of research. On the other hand, it seems evident the need to narrow the field of investigation in order to deepen a single aspect of the object and build, from it, highly specialized interpretative models. Between these two different approaches, the research presented aims to underline a certain circularity relationship; the discrete models generated by data-fusion processes and segmentation of point clouds are predisposed as analysis tools with their own autonomy; in the same way, continuous and parametric models favour the analysis process by directing, in a certain sense, the researcher's gaze. The possibility of arranging both the first and the second in a unique virtual environment is necessary for the transfer of the entire cognitive deck. The model thus understood is generated by the links that it is possible to think and build between the different information sources, these links represent the digital infrastructure supporting understanding. Each digital synapse activated allows the passage between different virtual spaces in which, from time to time, the reading of the model is transformed, it changes point of view answering new questions.

Fig. 7. Above, definition of the group of properties relative to the historical phases and the level of reliability of each element with the relative parameters. Below, general representation of the numerical model and the parametric model. Display of the reliability levels through graphic overwriting rules.
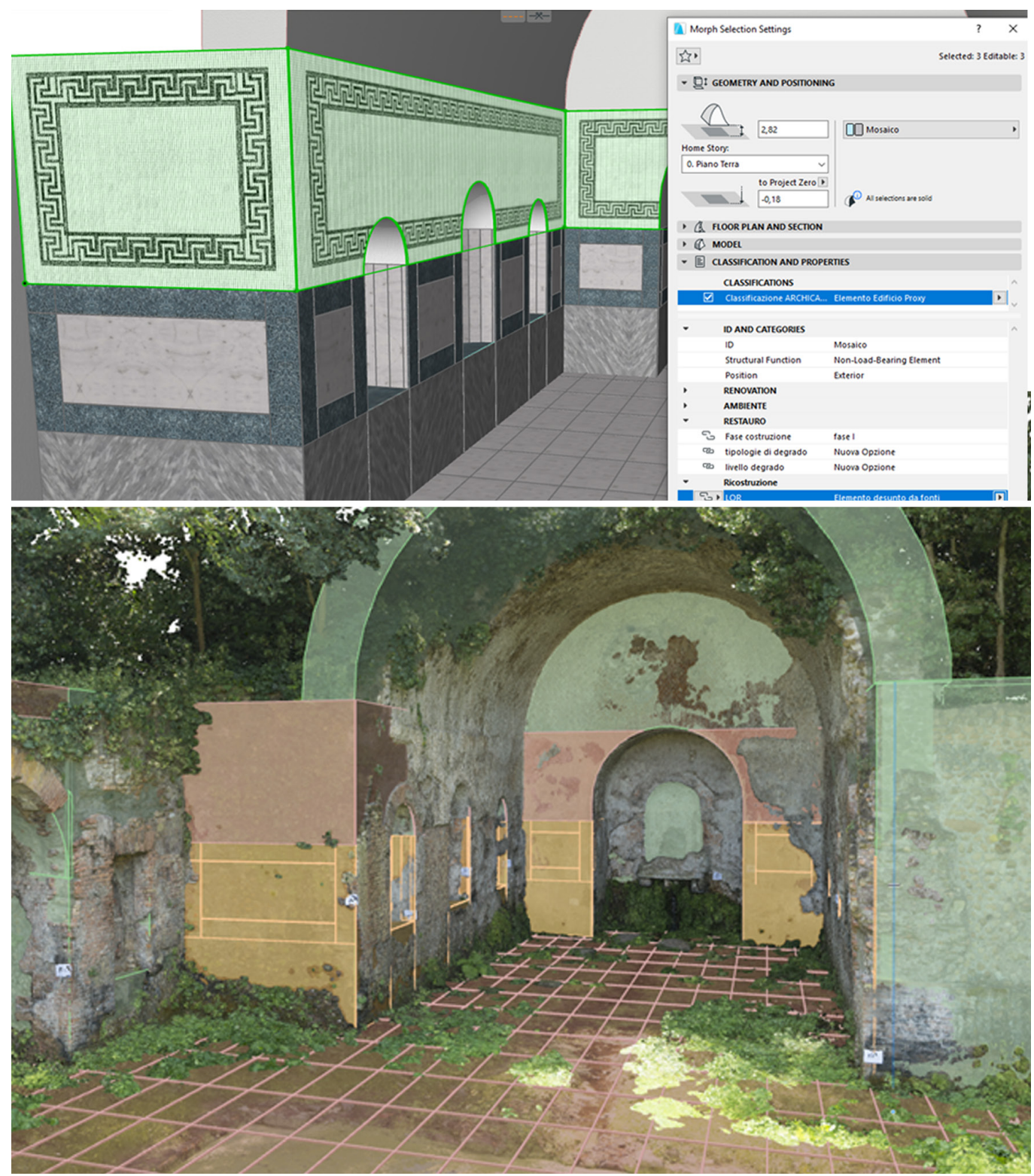


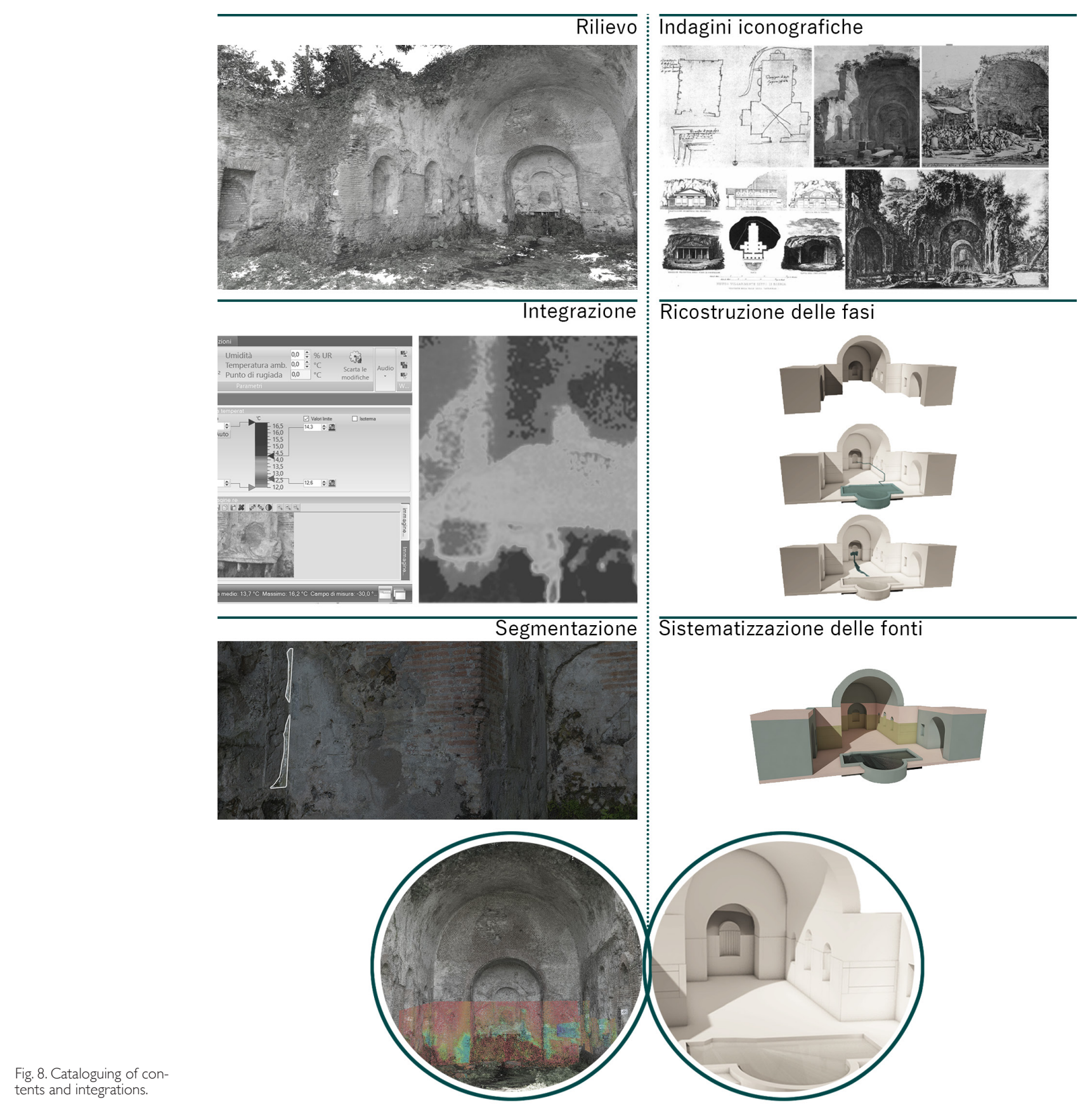




\section{References}

Ackoff Russell (1989). From data to wisdom. In Journal of Applied Systems Analysis, 16, 1989, pp. 3-9.

Apollonio Fabrizio Ivan (20 I5). Classification schemes and model validation of 3D digital reconstruction process. In Wolfgang Börner, Uhlirz Susanne (eds.). 20th International Conference on Cultural Heritage and New Technologies. Vienna: Museen der Stadt Wien - Stadtarchäologie, pp. I- I I.

Bianchini Carlo (20I2). La documentazione dei teatri antichi del mediterraneo. Roma: Gangemi Editore.

Bianchini Carlo, Nicastro Saverio (2018). The definition of the Level of Reliability: a contribution to the transparency of Historical-BIM processes. In Dn. Building Information Modeling, Data \& Semantics, 2, 2018 , pp. 46-59.

Boström Henrik, Andler Sten, Brohede Marcus, Johansson Ronnie, Karlsson Alexander, Laere Joeri, Niklasson Lars, Klingegård Maria, Persson Anne, Ziemke Tom (2007). On the definition of information fusion as a field of research. In Tech Report, HS-IKITR-07-006, pp. I-8

Calvano Michele (2019). Disegno Digitale Esplicito. Processi digitali per la rappresentazione della città, l'architettura, il prodotto, Ariccia: Aracne Editrice.

De Cristofaro Alessio (20 I4). II Ninfeo di Egeria nella valle della Caffarella a Roma. Forma, cronologia, funzione. In Orizzonti, $X V, 2014$, pp. 31-49.

Floridi Luciano (20 I 3). Information Quality. In Philosophy \& Technology, 26, 20 I 3, pp I-6.

Griffo Marika, Cimadomo Paolo, Menconero Sofia (2019). Integrative IRT for documentation and interpretation of archaeological structures. In Int. Arch. Photogramm. Remote Sens. Spatial Inf. Sci., XLII-2/W I , 20 I 9, pp. 533-539.

Khaleghi Bahador, Khamis Alaa, Karray Fakhreddine O., Razavi Saiedeh N. (20I3). Multisensor data fusion: A review of the stateof-the-art. In Information Fusion, I4, 2013 , pp. 28-44.

Lahat Dana, Adali Tulay, Jutten Christian (2015). Multimodal Data Fusion: An Overview of Methods, Challenges, and Prospects In Proceedings of the IEEE, I03, 2015, pp.1449-1477.

Ugo Vittorio (1994). Fondamenti della rappresentazione architettonica. Bologna: Società editrice Esculapio.

\section{Authors}

Carlo Bianchini, Sapienza Università di Roma, carlo.bianchini@uniroma l .it

Marika Griffo, Sapienza Università di Roma, marika.griffo@uniromal.it

To cite this chapter. Bianchini Carlo, Griffo Marika (2020). Digital synapsis: dati, informazioni e modelli in connessione/Digital synapsis: data, information, models in connection. In Arena A., Arena M., Brandolino R.G., Colistra D., Ginex G., Mediati D., Nucifora S., Raffa P. (a cura di). Connettere. Un disegno per annodare e tessere. Atti del $42^{\circ}$ Convegno Internazionale dei Docenti delle Discipline della Rappresentazione/Connecting. Drawing for weaving relationships. Proceedings of the 42th International Conference of Representation Disciplines Teachers. Milano: FrancoAngeli, pp. I $740-$ I 759. 